\title{
Serum Eosinophilic cationic protein (ECP) as an effective biological marker to monitor therapy in bronchial asthma patients.
}

\author{
Afroza Begum ${ }^{1}$, Humayun Sattar ${ }^{2}$, Abu Naser Ibne Sattar ${ }^{2}$, Md. Ruhul Amin Miah², Ahmed Abu Saleh² \\ ${ }^{1}$ Department of Microbiology, Enam Medical College, Savar, Dhaka, \\ ${ }^{2}$ Department of Microbiology and Immunology, Bangabandhu Sheikh Mujib Medical University, Shahbag, Dhaka.
}

\begin{abstract}
Clinically diagnosed bronchial asthma patients comprising of new cases, on therapy or follow up were enrolled for this study to see if the new biological marker Eosinophilic cationic protein (ECP) can be used as a more precise marker to monitor therapy than the presently used conventional ones like FEV1\% predicted, PEFR, and Circulating eosinophil (C.E) count. Out of 70 bronchial asthma patients, 30 intermittent, 4 mild persistent, 24 moderate persistent and 12 severe persistent asthma patients were included, while 45 cases were enrolled for follow up. Serum level of eosinophil granular protein, Eosinophilic cationic protein (ECP) was measured in relation to changes in their forced expiratory volume in 1st second (FEV1\% predicted) and Circulating Eosinophil count (\%) before and after therapy in 45 follow up patients on asthma therapy. In this study, it was observed that C.E count (\%) and FEV1\% predicted were not decreased significantly and serum eosinophilic cationic protein (ECP) decreased significantly $(p<0.001)$ after asthma therapy. Thus, serum ECP level can be used as a biological marker than other conventionally used marker (FEV1, C.E count) to monitor therapeutic efficacy in bronchial asthma patients.
\end{abstract}

Key words: Eosinophilic cationic protein, Forced expiratory volume in 1st second, Peak expiratory flow rate, Circulating eosinophil count.

\section{Introduction}

Bronchial asthma, is the chronic inflammatory disease of the airway and one of the important cause of morbidity as well as fatal in serious cases ${ }^{1}$. According to second National Asthma Prevalence Study (NAPS) 2010, in Bangladesh out of 150 million population, 10.5 million (7\% of the population) were suffering from bronchial asthma ${ }^{2}$.

Activated eosinophil play an important role in the pathogenesis of bronchial asthma. Eosinophils may contribute to airway hyper-responsiveness in asthma through the effects of eosinophil derived granular proteins on the bronchial epithelium $^{3}$. The matrix of the granule contain eosinophilic cationic protein (ECP), which is the cationic basic protein and

Correspondence:

Dr. Afroza Begum

Department of Microbiology

Enam Medical College, Savar, Dhaka.

Mob no. 01715496031

Email:afroza9697@yahoo.com other basic proteins (MBP, EDN, and EPO) ${ }^{4}$. These granule derived products having potent cytotoxic properties against bronchial epithelial cells and pneumocytes largely responsible for the damage associated with eosinophil infiltration in bronchial mucosa 5 .

Measuring of serum ECP levels have the advantages over eosinophil count as, it reflects not only the number of cells but also their degree of activation and therefore a better inflammatory marker ${ }^{6}$. Since, these proteins released from activated eosinophil researchers assume that circulating level of these proteins may be more specific marker for active inflammation than eosinophil count alone ${ }^{7}$.

A significant higher serum ECP levels are found in symptomatic asthma than asymptomatic ${ }^{8,9}$. On the other hand, serum ECP correlate more than eosinophil count in poor control of asthma and higher ECP level are found in uncontrolled asthma ${ }^{10}$. Serum ECP level also can be used to 
estimate the short term risk of deterioration and the need for corticosteroid treatment in cases of mild and moderate allergic asthma, thus it may have a useful role to play as a control parameter in asthma guideline ${ }^{11}$.

Measurment of serum ECP is helpful in determining asthma activity and deciding the use of antiasthmatic drugs ${ }^{12}$. Serum ECP levels are currently used for the clinical monitoring and diagnosis of inflammatory disorders ${ }^{13}$. High serum ECP level may be a predictor and a risk factor for asthma exacerbation and therefore be potentially useful for guiding treatment intensity ${ }^{14}$.

Serum ECP can be used as a measure of allergen provocation causing increased eosinophil activity ${ }^{8,13}$. Serum ECP can be used to assess the exposure to environmental allergens or decreasing presence of allergen in the environment and the need for increase or reduction of therapy ${ }^{14}$. Serum ECP level reflects about airway hyper-responsiveness, symptom onset, serum IgE level and it directly correlates with asthma severity, indirectly correlates with FEV1, disease activity throughout the year, seasonal asthma attack, PEFR measurements etc ${ }^{7,15}$.

The objective of the study was to assess serum ECP level as a biological marker than other conventionally used markers like FEV1, C.E count that will improve the reliability of the evaluation of the bronchial asthma patients to monitor therapeutic efficacy as well as adjust the doses of antiasthmatics.

\section{Materials And Methods:}

A total 70 clinically diagnosed bronchial asthma patients were enrolled in this study. Of them 30 were intermittent, 4 were mild persistent, 24 were moderate persistent and 12 were severe persistent asthma with age ranges from 5-70 years. Among 16 children, 14 were boys and 2 were girls and among 54 adults, 34 were female and 20 were male. Of the 45 disease controls, I5 were interstitial lung disease, 15 were chronic obstructive pulmonary disease and 15 were pulmonary tuberculosis patients. All cases and disease controls were selected from the patients attending the outpatient Department of National Institute of Disease of Chest and Hospital, Mohakhali, Dhaka (NIDCH) for the study during the period of July, 2010 to June, 2011. All the asthma patients fulfilled the internationally accepted GINA (Global Initiative for Asthma Management and Prevention) criteria ${ }^{16}$. The study was a cross sectional and part of the section was prospective type. All the laboratory works were performed in the Department of "Microbiology and Immunology", BSMMU, Dhaka.
At enrollment all patients underwent full clinical examination, pulmonary function tests (FEV1\% predicted), Bronchoprovocation test (who had normal lung function, FEV1 $80 \%$ predicted but symptoms were suggestive of asthma), PEFR, skin prick test (who had history of allergy and positive family history of atopy or allergy).

Circulating eosinophil (C.E) count was measured by automated cell analyzer, serum IgE level by sandwich ELISA method using commercially available test kit (DRG IgE, USA) and serum ECP by sandwich ELISA method using a commercially available kit (MBL MESACUP ECP ELISA kit, Japan). After 2 months of asthma therapy FEV1\% predicted, CE count and serum ECP level were measured among 45 bronchial asthma patients (on asthma therapy) to monitor the therapeutic effectiveness.

\section{Statistical Analysis:}

The qualitative and numerical data obtained from the study were entered in SPSS version - 16.0 for windows and analyzed. Test of significance was estimated by 't' test.

\section{Results:}

Of the 70 asthma patients, serum ECP level, CE count and FEV1\% predicted were measured in 45 patients to determine which marker would decrease significantly after 2 months of asthma therapy. In intermittent asthma both FEV1\% predicted and serum ECP level were not significantly decreased after 2 months of asthma therapy (Table-I).

Table I: Effect on FEV1 (\% predicted) and serum ECP level after 2 months of asthma therapy $(n=45)$

\begin{tabular}{|c|c|c|c|c|}
\hline \multirow[b]{2}{*}{ Study Group } & \multicolumn{2}{|c|}{ Before Therapy } & \multicolumn{2}{|c|}{ After Therapy } \\
\hline & $\begin{array}{c}\text { FEV1 } \\
(\% \text { predicted }) \\
\text { Mean } \pm \text { SD }\end{array}$ & $\begin{array}{c}\text { S.ECP level } \\
(\mathrm{ng} / \mathrm{ml}) \\
\text { Mean } \pm \text { SD }\end{array}$ & $\begin{array}{l}\text { FEV1 } \\
(\% \text { predicted }) \\
\text { Mean } \pm \text { SD }\end{array}$ & $\begin{array}{c}\text { S.ECP level } \\
(\mathrm{ng} / \mathrm{ml}) \\
\text { Mean } \pm \text { SD }\end{array}$ \\
\hline $\begin{array}{l}\text { Intermittent } \\
\text { asthma } \\
(n=18)\end{array}$ & $\begin{array}{c}86.80 \pm 3.5 \\
(80-92)\end{array}$ & $\begin{array}{c}6.78 \pm 2.38 \\
(0.8-10.38)\end{array}$ & $\begin{array}{c}86.31 \pm 5.3 \\
(80-95)\end{array}$ & $\begin{array}{l}7.19 \pm 3.9 \\
(0.8-7.9)\end{array}$ \\
\hline $\begin{array}{l}\text { Mild } \\
\text { Persistent } \\
\text { Asthma } \\
(\mathrm{n}=2)\end{array}$ & $\begin{array}{c}85.5 \pm 3.5 \\
(85-86)\end{array}$ & $\begin{array}{c}17.9 \pm 5.2 \\
(14.20-21.60)\end{array}$ & $\begin{array}{c}82.5 \pm 3.6 \\
(80-85)\end{array}$ & $\begin{array}{l}13.27 \pm 3.5 \\
(5.15-21.5)\end{array}$ \\
\hline $\mathrm{P}$ value & & $<0.047 \mathrm{~s}$ & & \\
\hline $\begin{array}{l}\text { Moderate } \\
\text { Persistent } \\
\text { Asthma } \\
(n=16) \\
\text { P value }\end{array}$ & $\begin{array}{c}65.63 \pm 5.6 \\
(60-79)\end{array}$ & $\begin{array}{c}28.81 \pm 14.7 \\
(16.79-68.5)\end{array}$ & $\begin{array}{c}70.75 \pm 6.4 \\
(67-95)\end{array}$ & $\begin{array}{l}18.85 \pm 12.01 \\
(5.14-39.05)\end{array}$ \\
\hline $\begin{array}{l}\text { Severe } \\
\text { Persistent } \\
\text { Asthma } \\
(\mathrm{n}=9) \\
\text { P value }\end{array}$ & $\begin{array}{c}55.43 \pm 12.6 \\
(18-55)\end{array}$ & $\begin{array}{c}94.76 \pm 70.5 \\
(34.6-190.5) \\
<0.001 \mathrm{~s}\end{array}$ & $\begin{array}{c}56.00 \pm 13.5 \\
(37-97)\end{array}$ & $\begin{array}{c}22.65 \pm 50.5 \\
(6.65-39.02)\end{array}$ \\
\hline
\end{tabular}

$\mathrm{s}=$ significant 
In mild persistent asthma patients, ECP value was $17.9 \pm 5.2$ $\mathrm{ng} / \mathrm{ml}$ before therapy and ECP value was declined significantly to $13.27 \pm 3.5 \mathrm{ng} / \mathrm{ml}(\mathrm{P}<0.047)$ after therapy but no significant difference was noted in FEV1\% predicted after therapy. Serum ECP level showed significant fall after 2 months of asthma therapy in case of moderate (before therapy $28.81 \pm 14.7 \mathrm{ng} / \mathrm{ml}$, after therapy $18.85 \pm 12.01 \mathrm{ng} / \mathrm{ml}, \mathrm{P}$ $<0.039$ ) and severe persistent asthma (before therapy $94.76 \pm 70.5 \mathrm{ng} / \mathrm{ml}$, after therapy $22.65 \pm 50.5 \mathrm{ng} / \mathrm{ml}, \mathrm{P}<0.001$ ). On the other hand, FEV1\% predicted was not decreased significantly in any categories of asthma after therapy. Serum ECP level showed a significant fall after 2 months of asthma therapy in mild, moderate and severe persistent asthma but C.E count was not significant decreased after therapy (TableII).

Table II: Effect on serum ECP level and CE count after 2 months of asthma therapy $(n=45)$

\begin{tabular}{|c|c|c|c|c|}
\hline \multirow[b]{2}{*}{ Study Group } & \multicolumn{2}{|c|}{ Before Therapy } & \multicolumn{2}{|c|}{ After Therapy } \\
\hline & $\begin{array}{l}\text { S.ECP level } \\
(\mathrm{ng} / \mathrm{ml}) \\
\text { Mean } \pm \text { SD }\end{array}$ & $\begin{array}{c}\text { C.E count }(\%) \\
\text { Mean } \pm \text { SD }\end{array}$ & $\begin{array}{l}\text { S.ECP level } \\
(\mathrm{ng} / \mathrm{ml}) \\
\text { Mean } \pm \text { SD }\end{array}$ & $\begin{array}{l}\text { C.E count }(\%) \\
\text { Mean } \pm \text { SD }\end{array}$ \\
\hline $\begin{array}{l}\text { Intermittent } \\
\text { asthma } \\
(\mathrm{n}=18)\end{array}$ & $\begin{array}{c}6.78 \pm 2.38 \\
(0.8-10.38)\end{array}$ & $\begin{array}{c}10.06 \pm 1.02 \\
(7-13)\end{array}$ & $\begin{array}{l}7.19 \pm 3.9 \\
(0.8-7.9)\end{array}$ & $\begin{array}{c}9.45 \pm 1.2 \\
(6-12)\end{array}$ \\
\hline $\begin{array}{l}\text { Mild } \\
\text { Persistent } \\
\text { Asthma } \\
(\mathrm{n}=2)\end{array}$ & $\begin{array}{c}17.9 \pm 5.2 \\
(14.20-21.60)\end{array}$ & $\begin{array}{l}10.37 \pm 4.0 \\
(8.75-12)\end{array}$ & $\begin{array}{l}13.27 \pm 3.5 \\
(5.15-21.5)\end{array}$ & $\begin{array}{c}10.05 \pm 3 \\
(7.5-11.5)\end{array}$ \\
\hline $\mathrm{P}$ value & $<0.047^{\mathrm{s}}$ & & & \\
\hline $\begin{array}{l}\text { Moderate } \\
\text { Persistent } \\
\text { Asthma } \\
(\mathrm{n}=16) \\
\mathrm{P} \text { value }\end{array}$ & $\begin{array}{c}28.81 \pm 14.7 \\
(16.79-68.5)\end{array}$ & $\begin{array}{c}11.03 \pm 3.5 \\
(7-13)\end{array}$ & $\begin{array}{l}18.85 \pm 12.01 \\
(5.14-39.05)\end{array}$ & $\begin{array}{c}10.78 \pm 3.0 \\
(6-12)\end{array}$ \\
\hline $\begin{array}{l}\text { Severe } \\
\text { Persistent } \\
\text { Asthma } \\
(\mathrm{n}=9) \\
\text { P value }\end{array}$ & $\begin{array}{c}94.76 \pm 70.5 \\
(34.6-190.5) \\
<0.001^{\mathrm{s}}\end{array}$ & $\begin{array}{c}12.86 \pm 8.41 \\
(7-14)\end{array}$ & $\begin{array}{l}22.65 \pm 50.5 \\
(6.65-39.02)\end{array}$ & $\begin{array}{c}11.76 \pm 7.46 \\
(7-12)\end{array}$ \\
\hline
\end{tabular}

$\mathrm{s}=$ significant

\section{Discussion:}

For diagnostic and prognostic purposes some conventional markers are being used by the physicians and investigators for the past years like FEV1\% predicted, C.E count, serum IgE level etc. Now, it has been suggested that eosinophil may contribute to airway hyperresponsiveness in asthma through the effects of eosinophil derived granular proteins on the bronchial epithelium such as ECP, MBP, EPO and EDN 1,3,4.
ECP is a cationic basic protein which is highly cytotoxic and largely responsible for the damage associated on bronchial epithelium in asthma ${ }^{5}$.

Recently, serum ECP is being widely studied and investigated to conclude it as a valuable marker for diagnosis and prognosis of bronchial asthma 11,12. Eosinophil count cannot differentiate between responders and non responders to asthma therapy which correlate with our study ${ }^{17}$. High S.ECP in well controlled asthma indicates the necessity of higher dose of therapy over a longer period than the condition when S.ECP concentration is not high. So, it can be used as a guideline for asthma exacerbation and treatment intensity. Therefore, assessment of serum ECP level is considered to reflect the degree of pulmonary inflammation in bronchial asthma.

In our study, a statistically significant fall of serum ECP was noted among mild, moderate and severe persistent asthma patients but not eosinophil count ( $\mathrm{p}$ value, <0.047, <0.039, $<0.001$ respectively). This study correlates with the study by Koller et al. (1995) which suggested that a significant decrease of serum ECP but not eosinophil count after therapy with budesonide for 4 wks and salbutamol for 2 wks ${ }^{8}$. Another study by Ishigaki ${ }^{18}$ reported that serum ECP reflects the allergic activity at least 2 wks prior to onset of exacerbation ${ }^{18}$.

Elevated ECP seems to denote patients at risk from inflammatory exacerbations, resulting in practical implications for the therapeutic management of chronic asthma ${ }^{19}$. ECP is a guide to tailing down inhaled corticosteroid therapy and assessment of compliance to most forms of anti-inflammatory therapies in asthma and guiding the tapering of inhaled corticosteroid in stabilized $\operatorname{asthmatics}^{20}$.

Spirometric measurments (FEV1) may not accurately reflect the extent of the inflammatory process in the airways and thereby do not always indicate the best choice of monitoring therapy which correlates with our study ${ }^{15}$. Our study correlates with the study by Vatrella et al. (1996) where it was reported that serum ECP could be used as a marker for monitoring the inflammatory component and the efficacy of antiinflammatory therapy in asthma ${ }^{15}$. Evaluation of the extent of eosinophil activation has been recently suggested as a more sensitive marker. Serum ECP is now accepted as an indicator of eosinophil activity. It appears to be the earliest indicator of allergen induced bronchial inflammation when changes in symptoms or in bronchial responsiveness are not yet evident ${ }^{15}$. 
Another study suggested the importance of serum ECP level as a marker to monitor therapeutic efficacy in asthma patients ${ }^{14}$. After withdrawal of corticosteroid, levels of ECP in serum increased at first visit and become significantly higher than those in the continuous treatment group and low levels of all eosinophil markers at baseline are associated with low risk of exacerbation in the withdrawal group. Thus, low levels of ECP can help to estimate the short term prognosis and the need for corticosteroid treatment over a limited time ${ }^{14}$. So, the results of this study suggest that, as serum ECP level decrease after therapy the patients who are on continuous treatment, no need for increase the dose of therapy. Thus, the principal usefulness of ECP is for the individual follow up and control of each patient. In order to control it, a suitable combination of different markers is needed which predictively improves the reliability of the diagnosis, prognosis and allow for a more precise control of the asthmatic inflammation ${ }^{21}$. In clinical practice ECP can be used as a marker to follow up therapeutic efficacy, to determine the correct dose of medication and may also indicate treatment failure as well as attacks and exacerbations when ECP concentration becomes high ${ }^{22}$.

The data in the present study suggested that the measurement of S. ECP can be used as biological marker to assess therapeutic effectiveness in bronchial asthma patients as well as to adjust doses of antiasthmatics.

In conclusion, the present data suggested that, serum ECP level but not circulating eosinophil count or FEV1\% predicted, can be used as an effective biological marker to monitor the therapeutic effectiveness in bronchial asthma patients.

\section{Aknowledgement:}

We aknowledge the staffs and Doctors of Department of Microbiology \& Immunology, Bangabandhu Sheikh Mujib Medical University, Shahbag, Dhaka and National Asthma Centre, National Institute of Disease of Chest \& Hospital, Mohakhali, Dhaka for their constant support in collecting the samples, laboratory works and management of patients.

\section{References:}

1. Samarai AGMA, Obaidi AHAA, Janabi JA and Samari AKYA. 2010. Role of Eosinophil Cationic Protein in Asthma and Confounding Factors, [web page at http://www.ispub.com/journal/the_internet_journal_of_ asthma_allergy_and_immunology.

2. Hassan MR. 2010. Trends of Asthma in Bangladesh, Findings of the National Asthma Prevalence Study (NAPS) 1999 \& 2010. Bangladesh Lung Foundation,
Dhaka, Bangladesh.

3. Fujimoto K, Kubo K, Matsuzawa Y and Sekiguchi M. Eosinophil cationic protein levels in induced sputum correlate with severity of bronchial asthma. Chest; 1997.112(5):1241-7.

4. Wardlaw AJ. 2001. Eosinophil trafficking in asthma. Clin Med; 1(3):214-18.

5. Bentley AM, Menz G, Sortz C, Roobinson DS, Bradley B, Jeffery PK et al. Identification of $\mathrm{T}$ lymphocytes, macrophages and activated eosinophils in the bronchial mucosa in intrinsic asthma: Relationship to symptoms and bronchial responsiveness. Am Rev Respir Dis; 1992. 146(2):500-6.

6. Koller DY, Halmerbauer G, Frischer T and Roithner R. Assessment of eosinophil granule proteins in various body fluids: is there a relation to clinical variables in childhood asthma? Clin Exp Allergy; 1999. 29(6):786793.

7. Sorkness C, McGill K and Busse WW. Evaluation of serum eosinophil cationic protein as a predictive marker for asthma exacerbation in patients with persistent disease. Clin \& Exp Allergy; 2002. 32(9):1355-6.

8. Koller DY, Herouy Y, Götz M, Hagel E, Urbanek R and Eichler I. Clinical value of monitoring eosinophil activity in asthma. Arch Dis Child; 1995. 73(5):413-7.

9. Zimmerman B, Lanner A, Enader I, Zimmermann RS, Peterson CG and Ahlstedt S. Total blood eosinophils, serum ECP and EPX in childhood asthma: reaction to disease status and therapy. Clin Exp Allergy; 1993. 23(7):564-70.

10. Zedan M, Settin A, El-Chennawi F, El-Desouky T, Nasef IN and Fouda A. Eosinophilic cationic protein; is it useful in assessing control of childhood asthma? East Med Health J; 2010. 16(10):1045-9.

11. Koh GCH, Shek LPC, Goh DYT, Bever HV and Koh DSQ. Eosinophilic cationic protein: is it useful in asthma? A systemic review. Respiratory medicine; 2007. 101:696-705.

12. Badr-El-Din OM, El-Sawy IH, El-Azzouni OE, Badr-ElDin MMA and Salem AM. Eosinophilic cationic protein as a serological marker of disease activity in childhood bronchial asthma. East Med H J; 1999. 5(4):664-675. 
13. Boix E, Leonidas DD, Nikolovski Z, Noguès MV, Cuchillo CM and Acharya KR. Crystal structures of eosinophil cationic protein at 2.4 A resolution. Biochemistry; 1999. 38(51):16794-801.

14. Oddera S, Silvestri M, Penna R, Galeazzi G, Crimi E and Rossi GA. Airway Eosinophilic Inflammation and Bronchial Hyperresponsiveness after Allergen Inhalation Challenge in asthma. lung; 1998. 176: 237-247.

15. Vatrella A, Ponticiello A, Parrella R, Romano L, Zofra S, Dileva A et al. Serum eosinophilic cationic cationic protein (ECP) as a marker of disease activity and treatment efficacy in seasonal asthma. Allergy; 1996. 51:547-55.

16. Bateman ED, Hurd SS, Barnes PJ, Bousquet J, Drazen JM, FitzGerld $M$ et al. GLOBAL GUIDELINES Global Strategy for asthma management and prevention: GINA executive summary. Eur Respir J; 2008. 31(10):143-178.

17. D'Amato G, Liccardi G, Russo M, Saggese M and D' Amato M. Measurment of serum level of eosinophil cationic protein to monitor patients with seasonal respiratory allergy induced by Parietaria pollen (treated and untreated with specific immunotherapy). Allergy; 1996. 51:245-50.
18. Ishigaki N, Masuhara C, Sakamaki K, Ishikawa Y, Ohta $\mathrm{K}$, Koike $\mathrm{R}$ et al. Relation between serum Eosinophil Cationic Protein (ECP) level and asthma attack in children. Arerugi; 2000. 49(11): 1093-103.

19. Chan PWK, Samsinah HH, Arpin HZ, Harm BP, Mustafa AM and Bruyne JA. Serum eosinophilic cationic protein (ECP) in asthmatic Malyasian children. Med J Malyasia; 2002. 57 (2): 201-203.

20. Koh GCH, Shek LPC, Goh DYT, Bever HV and Koh DSQ. Eosinophilic cationic protein: is it useful in asthma? A systemic review. Respiratory medicine; 2007. 101:696-705.

21. Nieto A. What role does Eosinophil cationic protein have in the evaluation of asthma severity? Allergol Immunopathol; 2000. 28(3): 119-24.

22. Cicak B, Verona E, Bukovac Z and Mihatov I. Asthma and Eosinophilic Cationic protein as an Indicator of Disease Control. Acta Clin Croat; 2005. 44: 251-257. 